\title{
Corruption and Economic Growth in the Balkan Countries
}

\author{
Amarda Kadia \\ European University of Tirana
}

\begin{abstract}
This paper examines the effect of corruption on public debt and economic growth. Empirical analysis verifies the channels that lead to an increase in the public debt, such as a rise in government spending, informal economy, infrastructure spending, always having a budget deficit financed through debt. The underlying hypothesis is that debt has a negative economic consequence in a country and austerity policies have more effect on countries with consolidated finances, while in developing countries such as Albania often bring an even higher growth of public debt. The final objective of this paper is the empirical verification of the idea that in developing countries, such as Albania and Balkan countries, public debt and corruption are inhibitors and deleterious for the economic growth.
\end{abstract}

Keywords: Corruption and Economic Growth in the Balkan Countries

\section{Introduction}

Expansion of corruption not only increases investments' costs and decreases their quality, but it also causes distortions in fiscal payments and a rise of the informal economy (Friedman et al., 2000). This creates a situation where investments are discouraged, FDIs are reduced (Abed \& Davoodi 2002), the funds used for education and health are restrained (Mauro, 1998), income redistribution gets aggravated (Olken, 2006), productivity is limited Lambsdorff \& Kyklos, 2003), economic growth is weakened, public spending increases and, consequently, a higher use of public debt is incentivized (Tanzi \& Davoodi, 2002).

According to Kaufmann (2010), politicians tend to stimulate large investments in infrastructure. This is achieved with an increase in public spending and debt growth. He demonstrates that corruption brings an increase in debt stock and as a consequence increases the costs for debt repayment in the future. All of this can often lead to a vicious circle of corruption and public debt.

In recent years, there has been a significant increase in debt attributed to the reconstruction of city centers in Albania. This initiative has not had an impact on employment or economic growth, yet, according to policymakers, it has strongly affected the social welfare of citizens.

However, a clearer idea of the impact of public debt on the country's economic growth will be explained and the empirical verification of the impact of corruption and debt in the economic growth in the last chapter. 


\section{Literature Review}

The literature gathers a common idea, which argues that a constant growth of public debt reduces the economic growth. (Reinhart \& Rogoff, 2010; Panizza \& Presbitero, 2014; Pattillo et al., 2002). Rubin et al., (2004) show that public debt does not only affect directly the economic downturn, but it also influences the investors by making them more cautious, because a state with a high public debt may not be able to repay debts to creditors. As a consequence, there will be an outflow of investors due to this debt, which will cause instability in the financial market.

Developing countries such as the Balkans must be cautious regarding the continued growth of the public debt, because not only will it not affect the economic growth, but it will also turn out to be inefficient for the development objectives (Chuhan \& Thomas, 2007).

The risk is higher when public policies are used for major investments in infrastructure to stimulate growth. This encourages corrupt behavior, which widens easily as a group (Tirole, 1996). The expansive corruption has negative effects on the cost and quality of investments and supports distortions in fiscal payments and growth of an informal economy (Friedman et al., 2000; Kaufmann, 2010).

According to Skidmore (1996) one of the many forms corruption becomes present is nepotism in the state administration, which touches even public hospitals where directors choose their own people or friends.

Similarly, in Albania it is quite often to see the majority of the public administration overflown with unskilled people purely because they are paying, are militants or close relatives of policymakers.

Friedman et al. (2000) demonstrates that corruption is accompanied by a rise of informal activities and inefficiencies in tax collection, reducing thus, the fiscal revenues, due to fiscal evasion. It is usually the least corrupt governments the ones that tend to hold a high fiscal pressure.

Johnson et al. (1997) says that fiscal evasion reduces fiscal revenue which is accompanied by a lower government's capacity to provide public goods and services. Dreher \& Schnëider (2010) reveal in their study that there is no established relationship between corruption and the informal economy. They confirm that corruption and the informal economy are somewhat verified in low-income countries, while in high-income countries no such relationship exists.

According to the abovementioned authors, the widening of the informal economy in developing countries positively contributes to the GDP growth.

In the study of Fiorino et. al. (2012) corruption can hinder competition and create delays in submitting documentations. As a result, it can lead to an increase of public service costs and notably reduce the investments and economic growth.

North (1990), speaks how an efficient judicial system which respects contracts can be an important factor in the economic performance. The security that comes for property rights, benefits and patents can significantly reduce incentives to invest, innovate and buy technology from abroad. 
Mauro (1995) adds that corruption leads to the formation of layers that hinder the uniform development of the population by increasing inequality, eliminating the middle class of the population and reducing total growth; the rich become richer and the poor become poorer. This also brings about the reduction of economic growth in general.

Other studies have shown that the lower the perceived corruption (10-30), the higher the economic growth will be for developed countries (2\%). Whereas for corruption that catches levels (60-70), the growth rate is zero or negative.

\section{Findings}

The Balkan countries we have taken into consideration for the empirical analysis are those part of EU such as Croatia, Romania, Bulgaria, Slovenia and countries aspiring to become members of EU such as Macedonia, Serbia. We have excluded Kosovo and Montenegro because of the lack of data as these are new countries that have only recently gained their independence. The first hypothesis is the one we raised in the analysis for Albania which says that good governance indicators are important for the economic growth of a country. This is based on the idea that these indicators are as important as corruption given that if they improve, corruption decreases as well.

The second one is that membership in the EU would positively help reducing corruption and increase the good governance indicators. This hypothesis takes place from the idea that Europe will impose strict rules so that politicians will no longer be able to misdirect public investments for corrupt motives, misuse public funds or choose unqualified people to work for the public administration. It is interesting how all of these countries demand the economic development to come from outside rather than internally.

If we look at the empirical models we have taken GDP growth as a dependent variable and Control of Corruption, Rule of Law and Government Effectiveness as explanatory variables. The software we have used continues to be Gretl.

The empirical model will be OLS and we will correct for heteroskedasticity. As a time series we have chosen the 15-year period from 2001-2016. We have not chosen a lot of years as all of our indicators are only estimates and as such the credibility of our paper would be low.

The number of observations is low, therefore we realize that our results are reliable but not $100 \%$. Additionally, we specify that GDP is a complex indicator that can be influenced by a relatively high number of factors. Whereas, the other explanatory variables considered do not necessarily stimulate the growth, but they serve as as a way to not halt it and increase credibility and attractiveness towards foreign investors. Additionally, a high good governance indicator means that a country would be more able to repay its debts and therefore helps the country to have a relatively low borrowing rate.

The first country to be considered will be Croatia, followed by Slovenia, Romania and Bulgaria, and then Serbia, Bosnia \& Herzegovina and Macedonia.

\section{Croatia}

Heteroskedasticity-corrected, using observations 2001-2016 ( $\mathrm{T}=16$ )

\section{Dependent variable: gdpgrowth}




$\begin{array}{llllll} & \text { Coefficient } & \text { Std. Error } & \text { t-ratio } & p \text {-value } & \\ \text { const } & 0.142213 & 0.00943395 & 15.07 & <0.0001 & * * * \\ \begin{array}{l}\text { ControlofCorruptionE } \\ \text { stimate }\end{array} & 0.0537806 & 0.0141491 & 3.801 & 0.0025 & * * * \\ \begin{array}{l}\text { GovernmentEffective } \\ \text { nessEstim }\end{array} & -0.170531 & 0.0290720 & -5.866 & <0.0001 & * * * \\ \begin{array}{l}\text { RuleofLawEstimate } \\ \text { Rut }\end{array} & -0.118237 & 0.0388089 & -3.047 & 0.0101 & * *\end{array}$

Statistics based on the weighted data:

$\begin{array}{llll}\text { Sum squared resid } & 21.72520 & \text { S.E. of regression } & 1.345524 \\ \text { R-squared } & 0.987058 & \text { Adjusted R-squared } & 0.983822 \\ \mathrm{~F}(3,12) & 305.0711 & \text { P-value(F) } & 1.37 \mathrm{e}-11 \\ \text { Log-likelihood } & -25.15009 & \text { Akaike criterion } & 58.30018 \\ \text { Schwarz criterion } & 61.39054 & \text { Hannan-Quinn } & 58.45843 \\ \text { rho } & 0.256162 & \text { Durbin-Watson } & 1.483183\end{array}$

Statistics based on the original data:

$\begin{array}{llll}\text { Mean dependent var } & 0.042482 & \text { S.D. dependent var } & 0.047784 \\ \text { Sum squared resid } & 0.011876 & \text { S.E. of regression } & 0.031459\end{array}$

When looking at Croatia, Control of Corruption has a positive effect although the coefficient is quite small. The results show that the Government Effectiveness and Rule of Law negative effect on the economic growth. The stricter the law, the lower are the chances of entrepreneurs to engage in new investments, especially in sectors that could hurt or pollute the environment. This effect is logical from an economic point of view.

As far as it regards the negative effect of Government Effectiveness, it is less intuitive. We could argue that sometimes abuses can stimulate growth in developing countries. Croatia has recently joined the $\mathrm{EU}$, which has most probably affected the businesses adapting to the changes the public institutions have been going through to become part of EU. However, we could always say that these indicators are estimates and can not always be taken as accurate.

The next linear empirical OLS model is the one of Slovenia, which is one of the most developed countries of the Balkans.

\section{Slovenia}

Heteroskedasticity-corrected, using observations 2001-2016 ( $\mathrm{T}=16$ )

Dependent variable: gdpgrowth 


\begin{tabular}{|c|c|c|c|c|}
\hline & Coefficient & Std. Error & t-ratio & $p$-value \\
\hline const & 0.605900 & 0.225691 & 2.685 & 0.0199 \\
\hline $\begin{array}{l}\text { ControlofCorruptionE } \\
\text { stimate }\end{array}$ & 0.0530952 & 0.0587170 & 0.9043 & 0.3837 \\
\hline $\begin{array}{l}\text { GovernmentEffective } \\
\text { nessEstim }\end{array}$ & 0.429602 & 0.173415 & 2.477 & 0.0291 \\
\hline RuleofLawEstimate & -0.187721 & 0.260965 & -0.7193 & 0.4857 \\
\hline
\end{tabular}

Statistics based on the weighted data:

$\begin{array}{llll}\text { Sum squared resid } & 36.84597 & \text { S.E. of regression } & 1.752283 \\ \text { R-squared } & 0.744292 & \text { Adjusted R-squared } & 0.680365 \\ \mathrm{~F}(3,12) & 11.64283 & \text { P-value(F) } & 0.000724 \\ \text { Log-likelihood } & -29.37628 & \text { Akaike criterion } & 66.75255 \\ \text { Schwarz criterion } & 69.84291 & \text { Hannan-Quinn } & 66.91080 \\ \text { rho } & 0.176830 & \text { Durbin-Watson } & 1.531941\end{array}$

Statistics based on the original data:

$\begin{array}{llll}\text { Mean dependent var } & 0.049783 & \text { S.D. dependent var } & 0.050194 \\ \text { Sum squared resid } & 0.035681 & \text { S.E. of regression } & 0.054529\end{array}$

The model portrays a positive impact of the Government Effectiveness on the GDP growth. The coefficient is relatively high, the standard error quite low and the $\mathrm{R}^{2}$ is high as well.

Surprisingly enough, Rule of Law and Control of Corruption are both not statistically significant although the sign is positive.

The following OLS model is the of Bulgaria.

\section{Bulgaria}

Heteroskedasticity-corrected, using observations 2001-2016 ( $\mathrm{T}=16$ )

Dependent variable: gdpgrowth

$\begin{array}{ccccc} & \text { Coefficient } & \text { Std. Error } & \text { t-ratio } & p \text {-value } \\ \text { const } & 0.0714058 & 0.0239675 & 2.979 & 0.0115\end{array}$ **




$\begin{array}{lllll}\begin{array}{l}\text { ControlofCorruptionE } \\ \text { stimate }\end{array} & 0.144103 & 0.0274557 & 5.249 & 0.0002\end{array}$ ***

Statistics based on the weighted data:

$\begin{array}{lcll}\text { Sum squared resid } & 48.82860 & \text { S.E. of regression } & 2.017189 \\ \text { R-squared } & 0.720598 & \text { Adjusted R-squared } & 0.650748 \\ \mathrm{~F}(3,12) & 10.31630 & \text { P-value(F) } & 0.001216 \\ \text { Log-likelihood } & -31.62884 & \text { Akaike criterion } & 71.25767 \\ \text { Schwarz criterion } & 74.34803 & \text { Hannan-Quinn } & 71.41592 \\ \text { rho } & 0.229980 & \text { Durbin-Watson } & 1.536672\end{array}$

Statistics based on the original data:

$\begin{array}{llll}\text { Mean dependent var } & 0.035625 & \text { S.D. dependent var } & 0.032243 \\ \text { Sum squared resid } & 0.009718 & \text { S.E. of regression } & 0.028458\end{array}$

From the results, we can infer that the impact of corruption in the GDP growth is relatively high and significant. Again, we notice a slightly insignificant effect of the Government Effectiveness and the Rule of Law. Additionally, the $\mathrm{R}^{2}$ is relatively high approximately 0.721 .

We then look at the empirical model for Romania.

\section{Romania}

\section{Heteroskedasticity-corrected, using observations 2001-2016 ( $\mathrm{T}=16$ )}

\section{Dependent variable: gdpgrowth}

$\begin{array}{llllll} & \text { Coefficient } & \text { Std. Error } & \text { t-ratio } & p \text {-value } & \\ \text { const } & 0.142206 & 0.0263069 & 5.406 & 0.0002 & * * * \\ \begin{array}{l}\text { ControlofCorruptionE } \\ \text { stimate }\end{array} & 0.289465 & 0.102178 & 2.833 & 0.0151 & * * \\ \begin{array}{l}\text { GovernmentEffective } \\ \text { nessEstim }\end{array} & 0.202798 & 0.0662357 & 3.062 & 0.0099 & * * * \\ \begin{array}{l}\text { RuleofLawEstimate } \\ \text { Rov }\end{array} & -0.339183 & 0.0620520 & -5.466 & 0.0001 & * * *\end{array}$


Statistics based on the weighted data:

$\begin{array}{lcll}\text { Sum squared resid } & 80.13110 & \text { S.E. of regression } & 2.584104 \\ \text { R-squared } & 0.750003 & \text { Adjusted R-squared } & 0.687504 \\ \mathrm{~F}(3,12) & 12.00019 & \text { P-value(F) } & 0.000634 \\ \text { Log-likelihood } & -35.59162 & \text { Akaike criterion } & 79.18324 \\ \text { Schwarz criterion } & 82.27359 & \text { Hannan-Quinn } & 79.34149 \\ \text { rho } & -0.186414 & \text { Durbin-Watson } & 1.847101\end{array}$

Statistics based on the original data:
Mean dependent var
0.038750
S.D. dependent var
0.039306
Sum squared resid
0.013642
S.E. of regression
0.033717

We can notice that there is a high positive impact that Control of Corruption and Government Effectiveness have on the GDP growth with coefficients of 0.2895 and 0.2028 respectively. The standard error is relatively low and $\mathrm{R}^{2}$ quite high.

Surprisingly, the impact of Rule of Law is negative. Law enforcement having a negative effect on the GDP growth is not intuitive, but it does have some grounds in the neo-liberalists theories, which support a free economy that has few interventions from the state. according to them if a country implements excessive controls and strict regulation it can substantially hurt the economy.

The rest of the analysis will be based upon the countries of the Western Balkans that are still aspiring to become part of the EU and are considered to have the highest level of corruption amongst Europe.

\section{Serbia}

\section{Heteroskedasticity-corrected, using observations 2001-2016 ( $\mathrm{T}=16$ )}

\section{Dependent variable: gdpgrowth}

\begin{tabular}{|c|c|c|c|c|c|}
\hline & Coefficient & Std. Error & t-ratio & $p$-value & \\
\hline const & -0.0325579 & 0.0377950 & -0.8614 & 0.4059 & \\
\hline $\begin{array}{l}\text { ControlofCorruptionE } \\
\text { stimate }\end{array}$ & -0.369614 & 0.105781 & -3.494 & 0.0044 & $* * *$ \\
\hline $\begin{array}{l}\text { GovernmentEffective } \\
\text { nessEstim }\end{array}$ & -0.330819 & 0.158057 & -2.093 & 0.0583 & $*$ \\
\hline RuleofLawEstimate & 0.0258497 & 0.0878633 & 0.2942 & 0.7736 & \\
\hline
\end{tabular}


Statistics based on the weighted data:

$\begin{array}{lcll}\text { Sum squared resid } & 21.92302 & \text { S.E. of regression } & 1.351635 \\ \text { R-squared } & 0.983113 & \text { Adjusted R-squared } & 0.978891 \\ \mathrm{~F}(3,12) & 232.8714 & \text { P-value(F) } & 6.75 \mathrm{e}-11 \\ \text { Log-likelihood } & -25.22260 & \text { Akaike criterion } & 58.44521 \\ \text { Schwarz criterion } & 61.53556 & \text { Hannan-Quinn } & 58.60346 \\ \text { rho } & -0.172962 & \text { Durbin-Watson } & 1.700248\end{array}$

Statistics based on the original data:

Mean dependent var

0.172717

S.D. dependent var

0.229112

Sum squared resid

0.176602

S.E. of regression

0.121313

This model portrays that a significant negative impact Control of Corruption has on the GDP growth. Surprisingly, it means that a growth in the corruption of a country can potentially lead to an increase in the GDP. Developing countries such as Serbia see this happen, because there are cases where foreign investors are incentivized to go to a country purely because there is corruption.

Imagine if there was the possibility to built a factory that has inefficient cheap filters and consequently pollutes the environment. This can only be achieved through the use of corruption. However, it leads to the creation of more jobs, decreases unemployment and leads to a growth of the economy regardless of the negative effect on the environment and long term economic growth. The impact of Government Effectiveness is also negative, based on the abovementioned reasoning.

\section{Macedonia}

Heteroskedasticity-corrected, using observations 2001-2016 ( $\mathrm{T}=16$ )

Dependent variable: gdpgrowth

\begin{tabular}{|c|c|c|c|c|}
\hline & Coefficient & Std. Error & t-ratio & $p$-value \\
\hline const & 0.0245551 & 0.0136831 & 1.795 & 0.0979 \\
\hline $\begin{array}{l}\text { ControlofCorruptionE } \\
\text { stimate }\end{array}$ & -0.0826753 & 0.0358710 & -2.305 & 0.0399 \\
\hline $\begin{array}{l}\text { GovernmentEffective } \\
\text { nessEstim }\end{array}$ & 0.109751 & 0.0689977 & 1.591 & 0.1377 \\
\hline RuleofLawEstimate & 0.0157324 & 0.0812009 & 0.1937 & 0.8496 \\
\hline
\end{tabular}


Statistics based on the weighted data:

$\begin{array}{lcll}\text { Sum squared resid } & 68.21795 & \text { S.E. of regression } & 2.384288 \\ \text { R-squared } & 0.528167 & \text { Adjusted R-squared } & 0.410209 \\ \mathrm{~F}(3,12) & 4.477581 & \text { P-value(F) } & 0.024943 \\ \text { Log-likelihood } & -34.30397 & \text { Akaike criterion } & 76.60794 \\ \text { Schwarz criterion } & 79.69829 & \text { Hannan-Quinn } & 76.76619 \\ \text { rho } & 0.369682 & \text { Durbin-Watson } & 1.177828\end{array}$

Statistics based on the original data:
Mean dependent var
0.027500
S.D. dependent var
0.024083
Sum squared resid
0.005966
S.E. of regression
0.022296

The empirical model for Macedonia show a relatively smaller negative impact of Control of Corruption in the GDP growth. Given that Macedonia is a developing country, we believe the reasoning is the same as the one we mentioned for Serbia. The coefficients for Government Effectiveness and Rule of Law are positive, yet statistically insignificant. However, the relatively high $\mathrm{R}^{2}$ shows the model is statistically significant.

\section{Conclusion}

The analysis showed the negative correlation that exists between corruption and economic growth. If we look closely at a country's economic performance, public debt, corrupton index and indeces of the governance indicators we can infer that all of these developing countries's politicians have pushed towards investments financed by debt in sectors where the possibility for corruption has been higher. Hence, they would need a good management of the public debt so that the public finances are not hurt. Most of these countries have all the resourses needed for a developed country, they have had high economic margins throughout the years, therefore a decrease in corruption and improvement of the government performance would be enough to generate rapid and high economic growth.

In conclusion, we can indicate that the economic growth and convergence of a country aspiring to reach the average level of the EU countries is directly related to the reduction of Control of Corruption, improvement of Government Effectiveness, the Rule of Law and Political Stability.

\section{Bibliography}

[1] Abed, G. and Davoodi, H., 2002, "Corruption, Structural Reforms, and Economic Performance in the Transition Economies," Chapter 18 in Governance, Corruption, and Economic Performance, ed. by George T. Abed, and Sanjeev Gupta, (Washington: International Monetary Fund).

[2] Acconcia, A., \& Cantabene, C. (2008). A big push to deter corruption: evidence from Italy. Giornale degli Economisti e Annali di Economia, 75-102.

[3] Bagnai, A. (2013). Declino, produttività, flessibilità, euro: il mio primo maggio. Blog post: http://goofynomics. blogspot. co. uk/2013/05/declino-produttivita-flessibilita-euro. html (Last access: 4-12-2014). 
[4] Cabezon, E., End, N., Slavov, S.\& Weller, A. (2017). Albania: Selected Issues; IMF Country Report No. 17/374; November 14, 2017.

[5] Checherita-Westphal, C., \& Rother, P. (2012). The impact of high government debt on economic growth and its channels: An empirical investigation for the euro area. European Economic Review, 56(7), 1392-1405.

[6] Cooray, A., Dzhumashev, R., \& Schneider, F. (2017). How does corruption affect public debt? An empirical analysis. World development, 90, 115-127.

[7] Friedman, E., Johnson, S., Kaufmann, D., \& Zoido-Lobaton, P. (2000). Dodging the grabbing hand: the determinants of unofficial activity in 69 countries. Journal of public economics, 76(3), 459-493.

[8] Greiner, A., \& Fincke, B. (2009). Public debt and economic growth (Vol. 11). Springer Science \& Business Media.

[9] Gupta, M. S., \& Abed, M. G. T. (2002). Governance, corruption, and economic performance. International Monetary Fund.

[10] Herndon, T., Ash, M., \& Pollin, R. (2013). Does High Public Debt Consistently Stifle Economic Growth? A Critique of Reinhart and Rogoff." Political Economy Research Institute Working Paper No.

[11] Johnson S, Kaufmann D and Shleifer A (1997) The Unofficial Economy in Transition, Brookings Papers on Economic Activity, 27, 159-239.

[12] Kaufmann, D. (2010). Can corruption adversely affect public finances in industrialized countries?. Brookings Institution, April, 19.

[13] Lambsdorff, J. G. (2003). How corruption affects productivity. Kyklos, 56(4), 457-474.

[14] Mauro P., (1995) "Corruption and growth", Quarterly Journal of Economics, vol.110, 681-712.

[15] Mauro, M. P. (1996). The Effects of Corruptionon Growth, Investment, and Government Expenditure (No. 96-98). International Monetary Fund.

[16] Mauro, P. (1998). Corruption and the composition of government expenditure. Journal of Public economics, 69(2), 263-279.

[17] Panizza, U., \& Presbitero, A. F. (2014). Public debt and economic growth: is there a causal effect?. Journal of Macroeconomics, 41, 21-41.

[18] Pattillo, C. A., Poirson, H., \& Ricci, L. A. (2002). External debt and growth (No. 2002-2069). International Monetary Fund.

[19] Pattillo, C. A., Poirson, H., \& Ricci, L. A. (2004). What are the channels through which external debt affects growth?.

[20] Reinhart, C. M., \& Rogoff, K. S. (2010). Growth in a Time of Debt (No. w15639). National Bureau of Economic Research.

[21] Rubin, R. E., Orszag, P. R., \& Sinai, A. (2004). Sustained budget deficits: the risk of financial and fiscal disarray. In AEA-NAEFA Joint Session, Allied Social Science Associations Annual Meetings.

[22] Tanzi, V., \& Davoodi, H. (2002). Corruption, public investment, and growth. In The welfare state, public investment, and growth (pp. 41-60). Springer, Tokyo. 